\title{
A TRITIUM VESSEL CLEANUP EXPERIMENT IN TFTR
}

\author{
by \\ M. CAORLIN, J. KAMPERSCHROER, D.K. OWENS, ET AL.
}

Published in the Proceedings of the 21st European Physical Society's Division of Plasma Physics Meeting (June 27-July 1, 1994, Montpellier, France), published by EPS 1994.

\section{Work supported by U.S. Department of Energy Contract DE- AC02-76-CH0-3073.}

\author{
DISCLAIMER
}

\begin{abstract}
This report was prepared as an account of work sponsored by an agency of the United States Government. Neither the United States Government nor any agency thereof, nor any of their employees, makes any warranty, express or implied, or assumes any legal liability or responsibility for the accuracy, completeness, or usefulness of any information, apparatus, product, or process disclosed, or represents that its use would not infringe privately owned rights. Reference herein to any specific commercial product, process, or service by trade name, trademark, manufacturer, or otherwise does not necessarily constitute or imply its endorsement, recommendation, or favoring by the United States Government or any agency thereof. The views and opinions of authors expressed herein do not necessarily state or reflect those of the United States Government or any agency thereof.
\end{abstract}

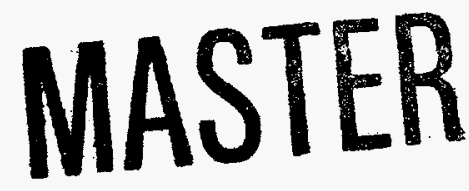

\section{Princeton University Plasma Physics Laboratory}




\section{DISCLAIMER}

Portions of this document may be illegible in electronic image products. Images are produced from the best available original document. 


\title{
A TRITIUMM VESSEL CLEANUP EXPERIMENT IN TFTR
}

\author{
M. Caorlin, J. Kamperschroer, D.K. Owens, C.W. Barnes', D. Voorhees, D. Mueller, \\ A. T. Ramsey, P.H. La Marche, M.J. Loughlin². \\ Princeton University, Plasma Physics Laboratory, PO Box 451, Princeton, NJ 08543, \\ USA. \\ ${ }^{1}$ Los Alamos National Laboratory, Los Alamos, NM 87545, USA. \\ 2 JET Joint Undertaking, Abingdon, Oxon, UK.
}

1. Introduction. The Tokamak Fusion Test Reactor began operations with deuterium and tritium mixtures in November 1993. A series of high power DT experiments injected about $13.3 \mathrm{TBq}(360 \mathrm{Ci})$ of tritium into the torus by $21 \mathrm{D}-\mathrm{T}$ neutral beam heated pulses, interspersed with $55 \mathrm{D}-\mathrm{D}$ pulses. As a result, some tritium was implanted into the walls and limiters. These experiments were followed by a short tritium cleanup experiment, which had to comply with operational constraints and with the need to maintain the high level of machine conditioning achieved. In the cleanup experiment, a series of deuterium ohmic shots interspersed with deuterium neutral beam injection shots was used to study the removal of tritium from the vessel.

2. Experimental. Table 1 lists the discharge parameters in the cleanup experiment. The discharge sequence consisted of two deuterium neutral beam fueled shots, for tritium diagnostic purposes, followed by four ohmic shots, for cleanup. This sequence was repeated 5 times. In beam-fueled shots, the beam power was varied between 2.5 and $7.5 \mathrm{MW}$.The number of DT-neutrons produced by the $D$ neutral beam

\begin{tabular}{||l|c|c|}
\hline \multicolumn{1}{|c|}{ PARAMETER } & UNIT & VALUE \\
\hline 1. Plasma current, $\mathrm{I}_{\mathrm{p}}$ & $\mathrm{MA}$ & 1.70 \\
\hline 2. Major radius, $\mathrm{R}_{\mathrm{p}}$ & $\mathrm{m}$ & 2.62 \\
\hline 3. Minor radius, $\mathrm{a}_{\mathrm{p}}$ & $\mathrm{m}$ & 0.97 \\
\hline 4. Toroidal field, $\mathrm{B}_{\mathrm{t}}$ & $\mathrm{T}$ & 4.50 \\
\hline 5. Deuterium beam power, $\mathrm{P}_{\mathrm{NB}}$ & $\mathrm{MW}$ & $0-7.5$ \\
\hline 6. Beam pulse length, $\mathrm{t}_{\text {beam }}$ & $\mathrm{s}$ & 1.0 \\
\hline 7. Flat-top duration, $\mathrm{t}_{\mathrm{t}}$ & $\mathrm{s}$ & 1.8 \\
\hline 8. Deuterium pre-fill pressure, $\mathrm{p}_{\mathrm{D} 2}$ & $\mathrm{~Pa}$ & $8 \times 10^{-4}$ \\
\hline
\end{tabular}

injection was measured by a calibrated neutron-activation detection system, based on ${ }^{28} \mathrm{Si}(\mathrm{n}, \mathrm{p})$ activity, with $10 \%$ accuracy, $7 \%$ shot-by-shot precision and a dynamic range of five decades [1]. This activation reaction with an energy threshold of $4.1 \mathrm{MeV}$, allows the rejection of any DD neutrons present. The ohmic discharges were adapted from 
standard TFTR He cleanup shots to have a major radius of $2.62 \mathrm{~m}$. For both beam and ohmic shots, the pre-fill gas was deuterium, to increase the tritium cleanup efficiency by isotopic exchange and desorption of DT molecules. The plasma major and minor radii were such that a very large plasma was created, so to "scrub" the largest possible area inside the torus. Figure 1 is a schematic of the TFTR vacuum system.

Following the high power D-T experiments, the cryopanels of beam line number 1 , (NBL 1 in figure 1), were regenerated. During the cleanup experiment only NBL 1 was open to the torus for injection and to provide pumping by the cryopanels. At the end of the cleanup discharges, NBL 1 was isolated from the torus and the beam line liquid-helium cryopanels were regenerated by puffing about 600 torr liters of $\mathrm{He}$ at 20 ${ }^{\circ} \mathrm{C}$ into the beam line. This raised the cryopanels temperature to above $20 \mathrm{~K}$ and relea-

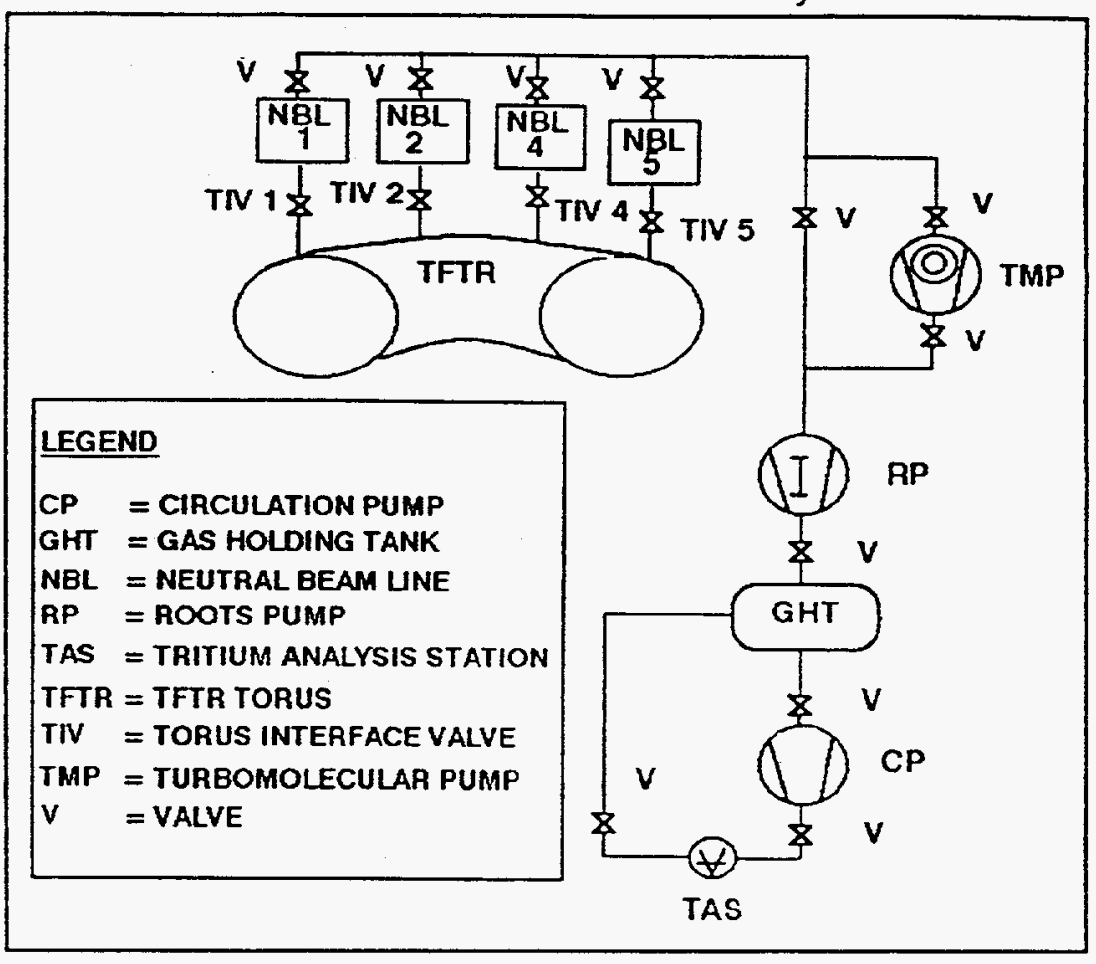

Figure 1: Schematic view of TFTR's vacuum system in use for this experiment.

sed most of the molecular deuterium and tritium.

The pressure in the sealed beam box raised to about 1 torr in this period. The beam box was evacuated in about 1 hour and the gas routed, through the pump RP, to one of the two Gas Holding Tanks (GHT) of the tritium system. The vacuum lines to the GHTs were purged with nitrogen to increase the tritium recovery efficiency. The gas received in the GHT was analyzed for quantity by PVT measurements, for gas composition by a calibrated quadrupole mass analyzer and for tritium content by means of an in-situ calibrated ionization chamber [2], placed in the Tritium Analysis Station TAS.

3. Results. After 34 pulses, about $1 \mathrm{TBq} \pm 1.8 \mathrm{TBq}(28 \mathrm{Ci} \pm 50 \mathrm{Ci})$ of tritium was recovered from the beam line cryopanels. The high estimated uncertainty (1.8 $\mathrm{TBq}$ ) is typical of measuring the amount of tritium recovered as difference between the tritium content of the GHT before and after regenerating the cryopanels. This amount represents about $8 \%$ of the amount of tritium previously injected by neutral beams into the torus during the high power DT experiments. The measurement of the amount of tritium recovered is however strongly influenced by the following factors: 1) efficiency of NB cryopanel regeneration, 2) efficiency in recovering tritium from vacuum lines by nitrogen purges, 3 ) accuracy of tritium sampling and analysis in the dynamic system 
associated with operation of the GHTs. The importance of these factors is unknown for the present measurements. The experience of this experiment suggests that in order to carry out measurements of tritium inventory in the torus based on differences between input and exhaust, a dedicated system is needed, comprising more than one plasma exhaust tank to receive only effluents from the torus and the beam lines. In addition, the amount of tritium retained in the torus is much smaller than that processed through the GHTs, i.e. on the order of $3 \%$, hence such system must have an accuracy of the order of $1 \%$ or better.

Figure 2 shows the variation of beam power $P_{\mathrm{NB}}$ expressed in $\mathrm{MW}$, of the plasma effective charge $Z_{\text {ett }}$ and of the electron central density $n_{e 0}$, as functions of the shot number. The cleanup was executed at $n_{\mathrm{e} 0}=2.7 \times 10^{19} \mathrm{~m}^{-3}$, except for one shot where the beam power was $2.5 \mathrm{MW}$. The effective charge $Z_{\text {eff }}$ increased during the experiment from 2.5 to about 4.3 , indicating that the plasma composition was passing from deuterium- to carbon-dominated. This was confirmed by the fact that the carbon CII light increased slightly while the $\mathrm{H}_{\alpha}+\mathrm{D}_{\alpha}$ light decreased. The $\mathrm{H} /(\mathrm{H}+\mathrm{D})$ ratio measured spectroscopically, remained constant around $12-14 \%$, a value typical of a wellconditioned vessel in TFTR. As a consequence the $D_{\alpha}$ light decreased, an indication of a decreased deuterium influx from the wall and limiters.

Figure 3 is a plot of the number of DT neutrons, $N_{D T}$, generated by the $1-$ second beam pulse and of the ratio $N_{D T} / P_{\mathrm{NB}}$. The latter accounts for beam power variations and has the same decreasing trend as that of $N_{D T}$. The value of $N_{D T}$, indicative of the tritium concentration in the plasma, decreased during the experiment from $4 \times 10^{15}$ to about $1 \times 10^{15}$, remaining well above the expected T-burnup level of $1 \times 10^{13}$. This decrease indicated that the amount of tritium available to the plasma from wall and limiters had diminished by the end of the cleanup experiment. After a fast initial decay in the number of neutrons, the rate of decay diminished. The tritium concentration in the plasma was too small to be detected spectroscopically, i.e. was below $2 \%$. This kind of discharge is useful to diminish the tritium recycling for fueling control, but is not efficient in removing tritium from low flux, co-deposition areas where most of the tritium retained in the torus is expected to be located [3]. For that task, other methods such as $\mathrm{He} / \mathrm{O}$ glow discharge cleaning, are necessary. This conclusion is very important for all-carbon machines and for TFTR, especially in view of tritium-abatement needs which may arise before decommissioning.

4. Summary. A simple tritium cleanup experiment was carried out in TFTR following the initial high power deuterium-tritium discharges in December 1993. A series of 34 ohmic and deuterium neutral beam fueled shots was used to study the removal of tritium implanted into the wall and limiters. A very large plasma was created in each discharge to "scrub" an area as large as possible. Beam-fueled shots at 2.5 to $7.5 \mathrm{MW}$ of injected power were used to monitor tritium concentration levels in the plasma by detection of DT-neutrons. The neutron signal decreased by a factor of 4 during the experiment, remaining well above the expected $T$-burnup level. The amount of tritium recovered at the end of the cleanup was about $8 \%$ of the amount previously injected with high power DT discharges. The experience gained suggests that measurements of tritium inventory in the torus are very difficult to execute and require 
dedicated systems with overall accuracy of $1 \%$.

Acknowledgements. This work was supported by US DoE contract no. DE-AC02$76 \mathrm{CH} 03073$.

\section{References.}

[1] C.W. Barnes et al., "Operation and cross calibration of the activation foil system on TFTR", Rev. Sci. Instr., 61 (1990), 3190.

[2] J.L. Anderson et al., "Operation of the TFTR tritium system during initial tritium experiments", presented at the 3rd International Symposium on Fusion Nuclear Technology, UCLA, Los Angeles, USA, June 27 - July 1, 1994.

[3] W.R. Wampler et al., "Deposition of carbon, deuterium and metals on the walls and limiters of TFTR", J. Vac. Sci. Technol. $\underline{6}$ (1988), 2111

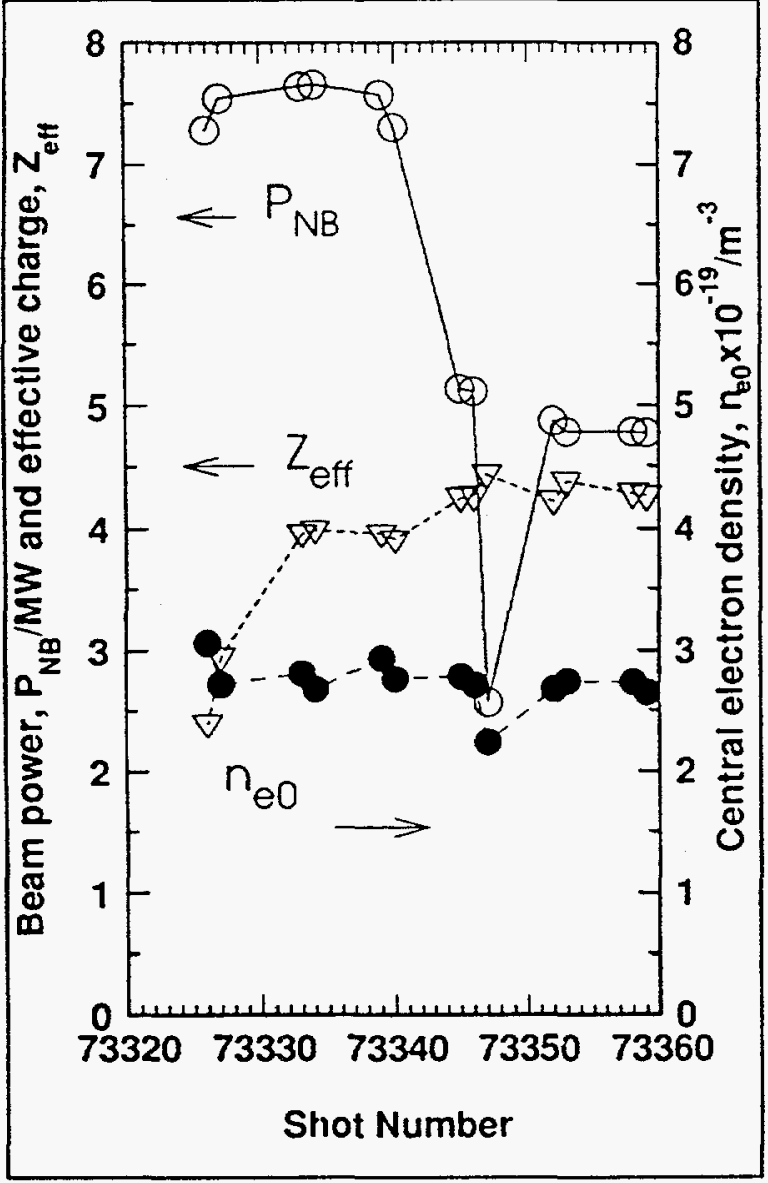

Figure 2: Variation of deuterium neutral beam injected power $P_{N B}(O)$, central electron density $n_{\mathrm{e} 0}(\bullet)$ and effective charge $Z_{\mathrm{ell}}(\nabla)$ during the experiment.

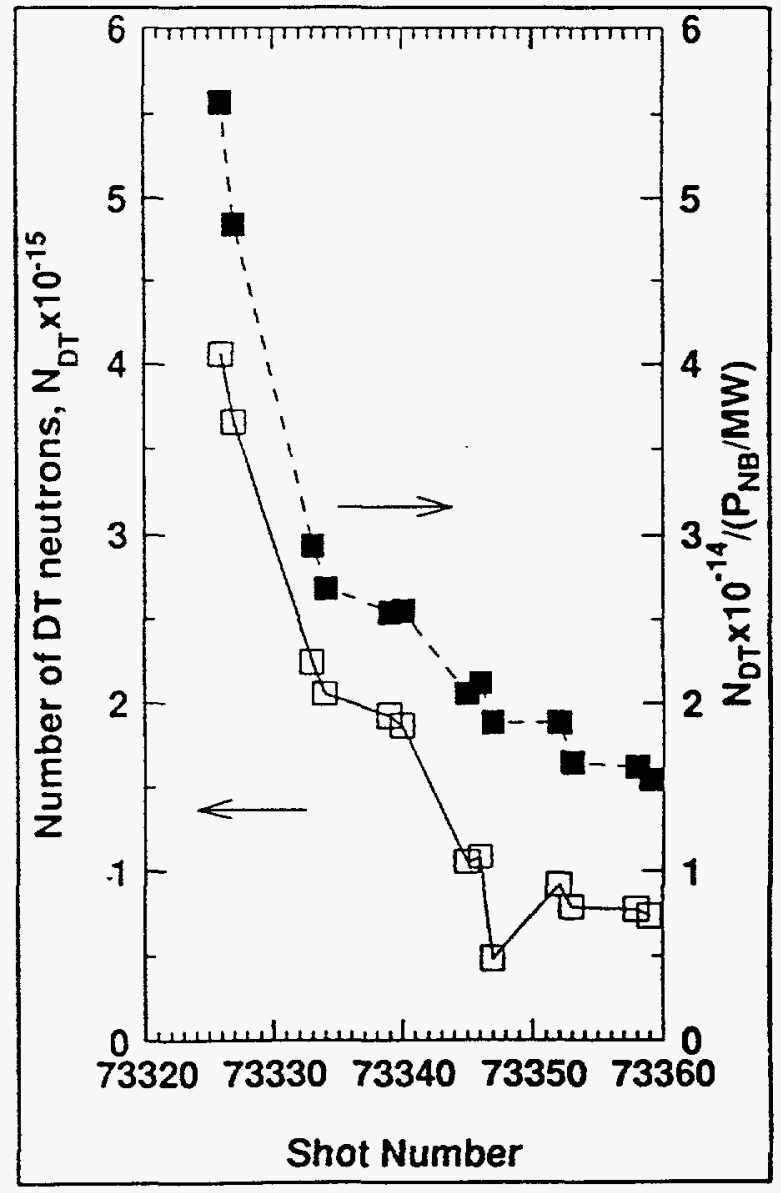

Figure 3: Plot of the number of DT neutrons $N_{D T}(\square)$ and of the ratio of $N_{D T}$ to beam power $\mathrm{P}_{\mathrm{NB}} / \mathrm{MW}(\boldsymbol{\square})$ measured during the experiment. 
Dr. F. Paoloni, Univ. of Wollongong, AUSTRALIA

Prof. R.C. Cross, Univ. of Sydney, AUSTRALIA

Plasma Research Lab., Australian Nat. Univ., AUSTRALIA

Prof. I.R. Jones, Flinders Univ, AUSTRALIA

Prof. F. Cap, Inst. for Theoretical Physics, AUSTRIA

Prof. M. Heindler, Institut für Theoretische Physik, AUSTRIA

Prof. M. Goossens, Astronomisch Instituut, BELGIUM

Ecole Royale Militaire, Lab. de Phy. Plasmas, BELGIUM

Commission-European, DG. XII-Fusion Prog., BELGIUM

Prof. R. Bouciqué, Rijksuniversiteit Gent, BELGIUM

Dr. P.H. Sakanaka, Instituto Fisica, BRAZIL

Prof. Dr. I.C. Nascimento, Instituto Fisica, Sao Paulo, BRAZIL

Instituto Nacional De Pesquisas Espaciais-INPE, BRAZIL

Documents Office, Atomic Energy of Canada Ltd., CANADA

Ms. M. Morin, CCFMTTokamak de Varennes, CANADA

Dr. M.P. Bachynski, MPB Technologies, Inc., CANADA

Dr. H.M. Skarsgard, Univ. of Saskatchewan, CANADA

Prof. J. Teichmann, Univ. of Montreal, CANADA

Prot. S.R. Sreenivasan, Univ. of Calgary, CANADA

Prof. T.W. Johnston, INRS-Energie, CANADA

Dr. R. Bolton, Centre canadien de fusion magnétique, CANADA

Dr. C.R. James, Univ. of Alberta, CANADA

Dr. P. Lukác, Komenského Universzita, CZECHO-SLOVAKIA

The Librarian, Culham Laboratory, ENGLAND

Library, R61, Rutherford Appleton Laboratory, ENGLAND

Mrs. S.A. Hutchinson, JET Library, ENGLAND

Dr. S.C. Sharma, Univ. of South Pacific, FIJI ISLANDS

P. Mähönen, Univ, of Helsinki, FINLAND

Prof. M.N. Bussac, Ecole Polytechnique,, FRANCE

C. Mouttet, Lab. de Physique des Milieux lonisés, FRANCE

J. Radet, CEN/CADARACHE - Bat 506, FRANCE

Prof. E. Economou, Univ, of Crete, GREECE

Ms. C. Rinni, Univ. of loannina, GREECE

Preprint Library, Hungarian Academy of Sci., HUNGARY

Dr. B. DasGupta, Saha Inst. of Nuclear Physics, INDIA

Dr. P. Kaw, Inst. for Plasma Research, INDIA

Dr. P. Rosenau, Israel Inst. of Technology, ISRAEL

Librarian, International Center for Theo Physics, ITALY

Miss C. De Palo, Associazione EURATOM-ENEA, ITALY

Dr. G. Grosso, Istituto di Fisica del Plasma, ITALY

Prof. G. Rostangni, Istituto Gas lonizzati Del Cnr, ITALY
Dr. H. Yamato, Toshiba Res \& Devel Center, JAPAN

Prof. I. Kawakami, Hiroshima Univ., JAPAN

Prof. K. Nishikawa, Hiroshima Univ., JAPAN

Librarian, Naka Fusion Research Establishment, JAERI, JAPAN

Director, Japan Atomic Energy Research Inst., JAPAN

Prof. S. Itoh, Kyushu Univ., JAPAN

Research Info. Ctr., National Instit. for Fusion Science, JAPAN

Prot. S. Tanaka, Kyoto Univ., JAPAN

Library, Kyoto Univ., JAPAN

Prof. N. Inoue, Univ. of Tokyo, JAPAN

Secretary, Plasma Section, Electrotechnical Lab., JAPAN

Dr. O. Mitarai, Kumamoto Inst. of Technology, JAPAN

Dr. G.S. Lee, Korea Basic Sci. Ctr., KOREA

J. Hyeon-Sook, Korea Atomic Energy Research Inst., KOREA

D.I. Choi, The Korea Adv. Inst. of Sci. \& Tech., KOREA

Prof. B.S. Liley, Univ. of Waikato, NEW ZEALAND

Inst of Physics, Chinese Acad Sci PEOPLE'S REP. OF CHINA

Library, Inst. of Plasma Physics, PEOPLE'S REP. OF CHINA

Tsinghua Univ. Library, PEOPLE'S REPUBLIC OF CHINA

Z. Li, S.W. Inst Physics, PEOPLE'S REPUBLIC OF CHINA

Prof. J.A.C. Cabral, Instituto Superior Tecnico, PORTUGAL

Prof. M.A. Hellberg, Univ. of Natal, S. AFRICA

Prof. D.E. Kim, Pohang Inst. of Sci. \& Tech., SO. KOREA

Prof. C.I.E.M.A.T, Fusion Division Libran, SPAIN

Dr. L. Stenflo, Univ. of UMEA, SWEDEN

Library, Royal inst. of Technology, SWEDEN

Prof. H. Wilhelmson, Chalmers Univ, of Tech., SWEDEN

Centre Phys. Des Plasmas, Ecole Polytech, SWITZERLAND

Bibliotheek, Inst. Voor Plasma-Fysica, THE NETHERLANDS

Asst. Prof. Dr. S. Cakir, Middle East Tech. Univ., TURKEY

Dr. V.A. Glukhikh,Sci. Res. Inst. Electrophys.I Apparatus, USSR

Dr. D.D. Ryutov, Siberian Branch of Academy of Sci., USSR

Dr. G.A. Eliseev, I.V. Kurchatov Inst., USSR

Librarian, The Ukr.SSR Academy of Sciences, USSR

Dr. L.M. Kovrizhnykh, Inst. of General Physics, USSR

Kernforschungsanlage GmbH, Zentralbibliothek, W. GERMANY

Bibliothek, Inst. Für Plasmaforschung, W. GERMANY

Prof. K. Schindler, Ruhr-Universitát Bochum, W. GERMANY

Dr. F. Wagner, (ASDEX), Max-Planck-Institut, W. GERMANY

Librarian, Max-Planck-Institut, W. GERMANY 